\title{
Den religiösa retoriken i A Token for Children - en puritansk barnboksklassiker från 1600-talet
}

\begin{abstract}
A Token for Children av James Janeway var förmodligen en av de första realistiska barnböckerna på engelska. Här presenteras en analys som visar att den religiösa retoriken inte bara innehåller religiösa budskap och didaktik utan även subversiva element. Artikelförfattaren frågar sig hur textens retorik är uppbyggd, hur den används och hur den förhåller sig till textens intention.
\end{abstract}

Barnboken A Token for Children: Being An Exact Account of the Conversion, Holy and Exemplary Lives, and Joyful Deaths, of several Young children (hädanefter kallad $A$ Token for Children) av den puritanske pastorn James Janeway (1636?-1674) var en av sin tids populära och inflytelserika barnböcker. I Förenta Staterna var den mot slutet av 1600-talet den mest rekommenderade boken för barn, näst efter Bibeln. ${ }^{1}$ Med $A$ Token for Children skapades en ny genre; den fromma, realistiska exempelberättelsen med döende barn som huvudkaraktärer.

A Token for Children trycktes i två delar 1671 respektive 1672 - och består av tretton berättelser, sex om flickor och sju om pojkar. Berättelserna om flickorna ges något större utrymme. De omfattar totalt 176 verser fördelade på 81 sidor medan berättelserna om pojkarna uppgår till 171 verser på 78 sidor. Den knappa övervikten till flickornas fördel beror främst på att den allra längsta berättelsen, som omfattar 70 verser, handlar om flickan Susanna Bicks. Versernas längd varierar mycket. Både avsnitt fem och sju består av 22 verser, men avsnitt fem omfattar sju sidor och avsnitt sju sträcker sig över 17 sidor.
Flickorna är alla namngivna utom en och bland pojkarna finns det tre som är anonyma. Alla berättelser utom två inleds med en uppräkning av barnens goda egenskaper samt exempel på deras fromma handlingar. Det framhävs att barnen är vetgiriga, duktiga $i$ skolan, nyfikna på religiösa frågeställningar och ivriga att utöva sin tro i form av bön, bibelläsning, familjeandakt och kyrkobesök. De predikar gärna för andra barn. Efter den inledande presentationen av barnen insjuknar de. Under sjukdomsperioden hemfaller de åt åkallan, bön, ångestfylld ånger för sina synder och de predikar för anhöriga, församlingsmedlemmar eller grannar. ${ }^{2}$ Berättelserna avslutas med barnens sista ord och död samt ofta någon kommentar som visar på det sublima i barnens döende, som i följande vers hämtad ur exempelberättelse två:

26. He still grew weaker and weaker, but carried it with a great deal of sweetness and patience, waiting for his change; and at last did chearfully commit his Spirit unto the Lord, and calling upon the Name of the Lord, and saying, Lord Jesus, Lord Jesus, - In whose bosome he sweetly slept, dying as I remember, when he was about five or six years old. ${ }^{3}$ 
Pojkens mod inför döden framhävs med orden "sweetness" och "patience" som ställs mot hans accentuerade svaghet. Döden beskrivs i positiva ordalag som "change". Det glädjefyllda och frivilliga i döendet visas med orden "chearfully commit his Spirit". "In whose bosome he sweetly slept" bekräftar slutligen att det är en fridfull, trygg och upphöjd död pojken går till mötes.

De allra flesta av barnen i exempelberättelserna växte upp i religiösa hem, men det finns två undantag. I berättelse sex och sju tas vilda, fattiga pojkar om hand av "goda kristna". Dessa avsnitt är intressanta eftersom de visar hur en systematisk manipulation kunde gå till. Vänlighet gentemot och omtanke om barnen i kombination med uppmuntran till bibelstudier och självrannsakan ses här som viktiga redskap i ansträngningarna att omvända barnen. Naturligtvis finns även hotet om helvetet med som motivation, ett vanligt tema i de puritanska predikningarna, men avsnitten visar att omtanke och omhändertagande måste komma först.

Den oftast refererade berättelsen är den om Sarah Howley, förmodligen därför att den kommer först. Den längsta och mest gripande berättelsen i A Token for Children handlar dock om en holländsk flicka, Susanna Bicks, en intellektuell och verbal 14åring. Det anmärkningsvärda med just den här berättelsen är den detaljerade utformningen av hennes långa predikningar, som ger intryck av att vara direkta citat, samt de många exemplen på det kärleksfulla förhållandet mellan flickan och hennes familj, förstärkt av styrande berättarkommentarer:

34. Being very feeble and weak, she said, $\mathrm{O}$ if I might quietly sleep in the bosome of Jesus! /.../ O Lord, grace! grace! and not justice, for if thou shouldest enter into judgment with me, I cannot stand, yea none living should be just in thy sight.
35. After this she cryed out, O how faint am I! but fearing least she should dishearten her mother, she said, while there is life there is hope: If it should please the Lord to recover me, how careful would I be to please you in my work and learning, and whatsoever you should require of me. ${ }^{4}$

\section{Svenska versioner}

De svenska versionerna av A Token for Children har omnämnts, om än inte analyserats, av B. Rud Hall (1943) $)^{5}$, Bengt Hellekant $(1944)^{6}$ och Göte Klingberg (1964) ${ }^{7}$. Klingberg kritiserar Hall ${ }^{8}$, hänvisar till Hellekant samt Harvey Darton (1932) ${ }^{9}$ och William Sloane (1955). De sistnämnda har författat de mest kända kommentarerna på vilka $\mathrm{i}$ stort sett all senare kritik vilar.

Några av Janeways berättelser förekommer i delar i D. Joh. Jacob Rambachs Vpbyggeliga barna-bok (1735, original på tyska utgiven 1734). A Token for Children översattes dock $i$ sin helhet till svenska först 1746 av rektor Olof Rönigk via en tysk översättning. Bokens fullständiga svenska titel är Andelig exempelbok för barn, thet är: en utförlig beskrifning, om àtskilliga unga barns omwändelse, heliga och exemplariska lefwerne, samt frögdefulla död; för thetta på engelska språket sammanfattad af Jacob Janneway, och nu, i förhoppning om någon nytto, i synnerhet til många gamlas utskämmande, upmuntran til efterfölgd, och til bewis, at en rätt christendom icke är i alla måtto omöjelig; efter then tyska öfwersättningen, på wårt modersmål, i liuset framgifwen, och med: några exempel tilökad. Stockholm, hos Johan Fridrich Lochner, år 1746. (Stockholm, tryckt hos Lorentz Ludwig Grefing, år 1746.) Denna egentliga första, svenska version innehåller utöver Janeways tretton berättelser tio skildringar av tyska barn ifrån den tyska upplagan samt åtta berättelser författade av Rönigk, varav flertalet var översättningar av separata, tyska texter. Den andra svenska utgåvan publicerades 
1766 och den tredje 1776. Det finns ytterligare en svensk version från 1798 som anger Janeway som författare, men den innehåller inte någon av Janeways berättelser utan endast ett urval ifrån det tyska tillägget och Rönigk. ${ }^{10}$

\section{Puritanismen och barnlitteraturen}

Ordet "puritansk" för tankarna till konservativa värderingar i en strängt religiös miljö. Associationen är inte helt vilseledande, även om den engelska och senare den amerikanska puritanismen stod för betydligt mer än så. Puritanismen uppstod som en engelsk missnöjesrörelse på 1500-talet. Det var särskilt korruption och dubbelmoral bland biskopar, prästerskap och munkar som upprörde de troende. ${ }^{11}$ Puritanerna anammade bland annat Jean Calvins (1509-1564) idéer. ${ }^{12}$ Calvins syn på det aktiva handlandet $\mathrm{i}$ samhället bidrog till puritanernas ivriga försök att genomdriva samhällsförändringar genom diskussioner, politiska aktioner, brev, böcker och andra skrifter. ${ }^{13}$ De stred bland annat för religionsfrihet, en öppen debatt och demokratisering av kyrkan, i vidare tillämpning senare av samhället.

På 1600-talet uppmärksammades barns läsning som aldrig förr, främst tack vare puritanernas stora intresse för barn och uppfostran. De puritanska författarna var först med att skriva böcker exklusivt för barn och de hade i stort sett monopol på böcker om barnuppfostran. Av 158 identifierade författare till barnböcker på engelska publicerade före 1710 var endast 54 utan någon puritansk eller annan närliggande, frikyrklig bakgrund. ${ }^{14}$

Jag har inte funnit någon statistik, men när man läser A Token for Children och noterar den betydelse som barnens studier ges ligger det nära till hands att dra slutsatsen att läskunnigheten ökade med puritanis-

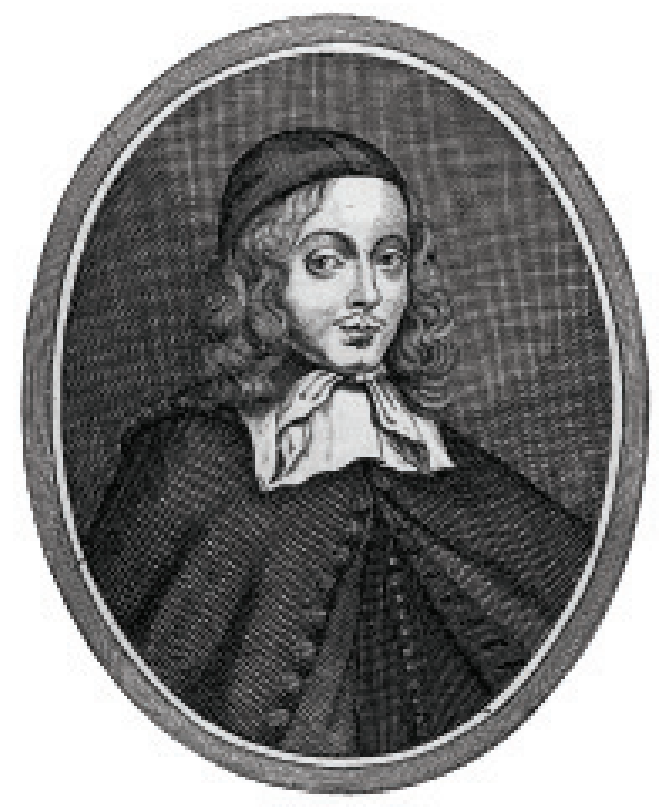

III. James Janeway ur Children's literature. An illustrated history, ed. Peter Hunt (1995).

men. I Amerika tycks läsundervisningen ha börjat med puritanerna, som Anne Scott MacLeod skriver:

The story of children's reading in America begins with the Puritans. Although they were hardly the only settlers in a vast new land, the circumstances of their coming, the nature of their settlements, and the attitudes they brought with them had influence beyond their numbers on early American cultural history and on the development of an American literature for children /.../ As Protestants they read the Bible and sanctioned no priesthood between themselves and their God. /.../

It was imperative, then, that their children read and learn, from books as well as from parents /.../ From the beginning, Puritans thought about children and provided for their schooling, at home and in the tiny settlements they called towns. By the 1640s, Massachusetts law required heads of families to teach their children and apprentices to 
read. No one, the law said, 'should suffer so much barbarism in any of their families as not to indeavor to teach... their children and apprentices so much learning as may inable them perfectly to read the english tongue'. 'Ignorance', wrote Increase Mather [en känd, ledande puritan], 'is the Mother... of HERESY.' ${ }^{15}$

MacLeod uppmärksammar här en särskilt intressant detalj, nämligen att puritanerna inte accepterade något prästerskap som uttolkare av Bibeln. Det skulle inte finnas någon människa mellan individen och Guds ord. Bibeln skulle läsas och tolkas av varje troende. Därför blev läskunnigheten viktig. När det gäller strävan efter annan kunskap än den rent religiösa kan den förklaras av idén om att de troende aktivt skulle påverka samhället.

John Sommerville skriver i sin studie The Discovery of Childhood in Puritan England (1992) att puritanska och frikyrkliga barnboksförfattare gick i täten för den realistiska beskrivningen av barndomen. ${ }^{16}$ Puritanerna presenterade en helt ny syn på barndomen. Det nya låg i variationen och de individuella detaljerna, vilka var förutsättningarna för en trovärdig realism. ${ }^{17}$ Sommerville påstår också att 1600-talets berättelser om barn innehöll färre hemligheter än texter om vuxna. Författarna avslöjade mer och därmed blev skildringar av barn mer realistiska. ${ }^{18}$

\section{Kompositionen}

A Token for Children var den första barnbok (på engelska) som endast innehöll berättelser om samtida, engelska barn. ${ }^{19}$ Skildringarna bygger sannolikt på verkliga personer och händelser. Däremot måste texternas autenticitet ifrågasättas, eftersom de har underkastats en retorisk bearbetning. Janeways påstående att dessa berättelser är sanna biografier är retoriskt sett ett enkelt och genialt grepp. Barnen är hjältar, trots att de är vanliga barn. De beskrivs realistiskt i situationer och miljöer som läsaren bör ha känt igen. Det talas om skola, katekesinlärning, stränga lärare, religiösa "plikter", för tiden och kulturen kända böcker, söndagspredikningar, stränga/kärleksfulla/dåliga föräldrar, sjukdom och död. Något övernaturligt finns inte beskrivet i samband med något barns död, utan texten förblir realistisk. I några fall säger barnen sig se syner, men barnens ord återges i citat, utan berättarkommentar. Det närmaste man kan komma något övernaturligt är att barnen i ett par fall gör en förutsägelse om vilken dag de ska dö (se exempelberättelse fem och sju), vilket visar sig slå in. Janeways text kan ses som ett ypperligt exempel på den realism Sommerville talar om.

Att det inte finns någon beskrivning av otroliga, övernaturliga fenomen beror på realismens dubbla funktion; att skapa identifikation och visa doktrinens praktiska tillämpning. Att ge barn orealistiska förväntningar på uppenbarelser och mirakel skulle kunna minska deras tro och tillit till det som inte syns, utan kanske enbart kan kännas.

Texten i A Token for Children präglas helt av det religiösa budskapet. Den överdidaktiska berättarröstens stelbenta retorik är ett så dominerande stildrag att detta i sig blir det mest konkreta dilemmat. Berättelserna är episka, men saknar en dramatisk struktur. Kompositionen följer dock ett givet mönster, som återkommer i varje berättelse. Det är därför relevant att fråga sig: Hur är textens retorik uppbyggd, hur används den och hur förhåller den sig till textens intention? Denna frågeställning ligger till grund för undersökningen.

De flesta av de puritanska barnboksförfattarna var liksom Janeway utbildade teologer/pastorer, som hade studerat den klas- 
siska retoriken. I Puritan Rhetoric: The Issue of Emotion in Religion (1972) av Eugene White finns uppgifter om de texter i retorik som studerades på universiteten vid den aktuella tidpunkten. Några kända namn framträder som särskilt stilbildande beträffande den puritanska metoden att arbeta fram predikningar; Aristoteles, Peter Ramus (P. Rami Regii Professoris Dialecticae Libri Duo, Lutetiae, $1574^{20}$ ), Gerard Vossius (Rhetorices Contractae, sive Partitionum Oratoriarum, Oxford $\left.1631^{21}\right)$, William Perkins (1558-160222) och John Udall (1560?-159223). Praktiska modeller utarbetades av de två sistnämnda, som enligt White innebär att talet indelas i fyra delar. En predikan skulle inledas med en redovisning, vanligen en sammanfattning, av temat, oftast genom att man citerade eller läste en bibeltext. Det kallas "laying open the text". ${ }^{24}$ Den andra delen av predikan kallade Perkins "doctrine". Här valdes några viktiga argument utifrån bibeltexten. I den tredje delen, kallad "reasons", skulle doktrinens/argumentens sanningshalt bevisas. Ibland infogades invändningar, "objections", som talaren besvarade. Syftet med den sista delen, "application", var att visa på praktiska exempel, enligt Perkins; hur doktrinen kunde tillämpas i vardagslivet. ${ }^{25}$ Det var i denna del som det var fritt fram att använda känslomässig argumentering och känsloladdade uttryck för att entusiasmera församlingen. ${ }^{26}$

Textens struktur tyder på att Janeway skrev berättelserna enligt samma retoriska riktlinjer som en tidsenlig predikan av ovanstående typ. Bokens långa titel är ett exempel på "laying open the text". Här presenteras vad texten kommer att handla om. Det gäller även bibelcitaten på försättsbladen. ${ }^{27}$

Doktrinen preciseras i Janeways två förord i den första delen av A Token for Children och upprepas i berättelserna. Att sträva efter fromma egenskaper och gudfruktiga handlingar framstår som textens viktigaste budskap.

Den första delen av Janeways berättelser ägnas åt "reasons"; att intellektuellt bevisa att barnet som skildras är fromt. Den retoriska teknik som används är att dels komma med påståenden om barnets egenskaper och handlingar, dels illustrera detta genom exemplifierande anekdoter ur barnets liv.

Det visar sig att punkt tre och fyra - "reasons" respektive "application" - delvis sammanfaller i berättelsernas första del. I den logiska argumenteringen ("reasons") används exempel som bevis, som samtidigt visar hur doktrinen kan tillämpas i det verkliga livet ("application"). Det dominerande intrycket är dock att den första delen av berättelserna ägnas åt intellektuell argumentering för barnens fromhet, medan retoriken $\mathrm{i}$ den senare delen blir betydligt mer känslomässig och därmed övergår till att vara ett mer renodlat exempel på "application". Kontrasterna mellan retoriken i den första respektive andra delen av varje berättelse är slående.

\section{Barnen - en gåva från Gud}

I en närmare bekantskap med förorden framgår att Janeways välmenande intention var att texterna skulle skänka barnen glädje, samtidigt som de skulle hjälpa barnen att stärka sin tro och undgå ett fruktansvärt öde i helvetet. ${ }^{28}$ Janeway inleder boken med följande förmaning till föräldrar och lärare:

\section{Dear Friends,}

I Have oft thought that Christ speaks to you, as Pharaoh's Daughter did to Mose's Mother; Take this Child and Nurse it for me. O Sirs, consider what a precious Jewel is committed to your charge, what an advantage you have to shew your love to Christ, to stock the next Generation with Noble Plants, and what a 


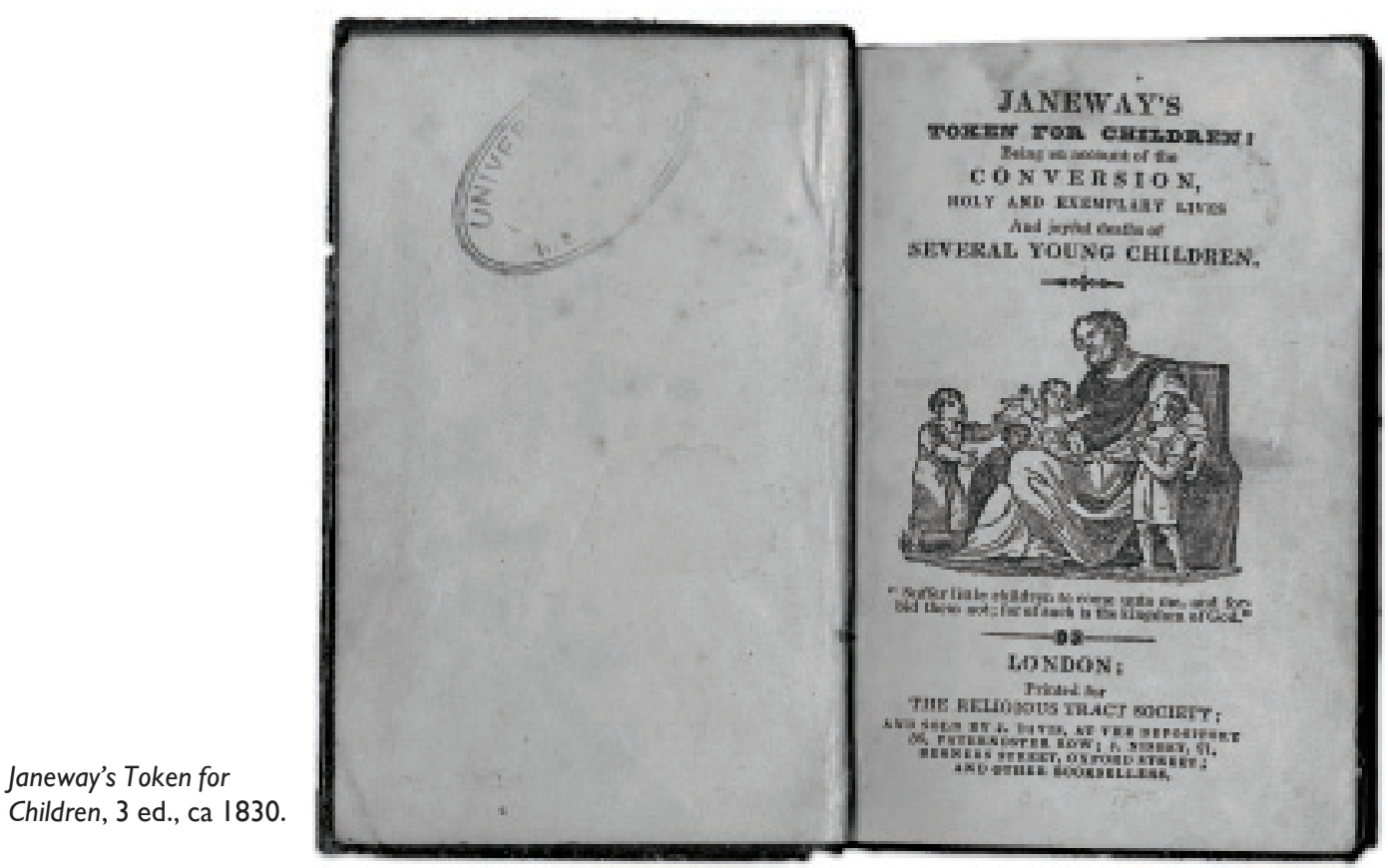

joyful account you may make, if you be faithful: Remember, Souls, Christ, and Grace, cannot be over-valued. ${ }^{29}$

Av citatet framgår att Janeway såg barnen som en gåva från Gud och att föräldrarna hade fått en särskild möjlighet att visa sin kärlek till Kristus genom omsorg om sina barn. Avsnittets placering och känslosamhet vittnar om hur viktigt det var för Janeway att tala om för föräldrar hur betydelsefull deras roll som kärleksfulla uppfostrare var. Därmed avvisar han naturligtvis inte bestraffningar eller skrämselpropaganda, men det är viktigt att beakta att syftet inte var att skrämma barnen till lydnad, utan att leda dem till deras egen religiösa kallelse. Att leda någon till en personlig övertygelse kan ses som (och är) en motsägelse. Det Janeway talade om var att skapa förutsättningarna, men en verklig omvändelse kunde, enligt doktrinen, bara ske med hjälp av Guds nåd. ${ }^{30}$
Janeways förhoppning var att den unga generationen inte skulle se bokens hjältar som upphöjda och ovanliga helgon, utan som förebilder att identifiera sig med, ta efter och försöka överträffa. Han skriver:

/.../ That the young generation may be far more excellent than this, is the Prayer of one that dearly loves little Children. ${ }^{31}$

Det ovanliga med barnen i Janeways texter var inte att de uppfyllde sina föräldrars och andra vuxnas förväntningar, utan att de överträffade förväntningarna och uppvisade en egen fromhet och övertygelse. Som exempel på detta kan nämnas att de själva tog initiativet till religiösa handlingar och ivrigt predikade för andra.

\section{Hur känna igen ett fromt barn?}

Janeway skrev två förord till den första delen av A Token for Children. Det första riktar sig 
till "Parents, School-masters and SchoolMistresses, or any that have any hand in the Education of Children." 32 Det andra riktar sig till barn och är bokens egentliga förord tillika läsanvisning, vilket framgår av den otvetydiga rubriken" A PREFACE: Containing DIRECTIONS TO CHILDREN." 33 I förorden används arvssynden som ett argument för tidig omvändelse. ${ }^{34}$ Tanken är att synden finns i oss från födseln och att det därför är bättre ju tidigare barnet inser sin syndfulla natur och omvänder sig. I det andra förordet finns skrämmande beskrivningar av vad som händer om man inte aktar sig för synden:

3. Whither do you think those Children go, when they dye, that will not do what they are bid, but pay the Truant, and Lye, and speak naughty words, and break the Sabbath? Whither do such Children go, do you think? Why, I will tell you, they which Lye, must go to their Father the Devil into everlasting burning; they which never pray, God will pour out his wrath upon them; and when they beg and pray in Hell Fire, God will not forgive them, but there they must lye for ever. ${ }^{35}$

För att förtydliga bilden av helvetet gör Janeway en jämförelse med situationer läsaren bör vara bekant med:

/.../O Hell is a terrible place, that's worse a thousand times than whipping; Gods anger is worse than your Fathers anger /.../ ${ }^{36}$

Att författaren försöker motivera läsaren med hot är uppenbart, men positiva effekter av ett fromt liv framhävs också. Belöningen blir inte bara Guds kärlek och ett evigt liv i himmelriket, utan även här på jorden får det fromma barnet andra människors kärlek och respekt:

1. Were not these Children sweet Children, which feared God, and were dutiful to their Parents? Did not their Fathers and Mothers, and every body that fears God, love them, and praise them?
What do you think is become of them, now they are dead and gone? Why, they are gone to Heaven, and are singing Hallelujahs with the Angels: They see glorious things, and having nothing but joy and pleasure, they shall never sin no more, they shall never be beat any more, they shall never be sick, or in pain any more. ${ }^{37}$

Utöver skillnaden i tilltal, vissa pekpinnar angående barnuppfostran i det första förordet samt en mer detaljerad och predikande text $\mathrm{i}$ det andra består båda förorden av religiös argumentering samt uppräkningar av dygder, påbud att sträva efter samt synder att undvika. Dessa dygder och regler är Janeways svar på frågan: Hur kan man känna igen ett fromt barn? Om man sammanfattar förordens och textens inställning till vad som förväntades av ett puritanskt barn kan man säga att barnen skulle: undvika lek och synd, ägna sig åt nyttiga sysslor, undvika dåligt sällskap, helga sabbaten, lyda och respektera sina föräldrar, studera flitigt (läsa, fråga och diskutera), be och/eller gråta i ensamhet, ägna sig åt självrannsakan, göra goda gärningar och/eller visa empati, predika, be till/åkalla/glorifiera/tacka Gud/ Jesus, få eller söka andra människors kärlek, respekt och/eller böner samt deltaga i eller utföra religiösa aktiviteter i hemmet eller kyrkan.

För en modern läsare är kanske det märkligaste påbudet att barnen skulle be i ensamhet och då helst gråta. I texterna nämns att föräldrar står utanför dörren och lyssnar. Ibland blir grannarna störda av det ihärdiga gråtandet. Det kan verka grymt, men ur ett puritanskt perspektiv var en åkallan och bön som blev så intensiv och fylld av självrannsakan att barnet började gråta ett tecken på uppriktighet, ödmjukhet och upphöjd fromhet, det vill säga något att beundra. ${ }^{38}$

Vid en kvantitativ undersökning visade det sig att ovannämnda tecken på fromhet 
får ett stort utrymme i texten, särskilt studier och predikan. Att barnens vetgirighet och studieiver nämns så ofta som sammanlagt 106 gånger i texten visar vilken stor betydelse studier hade i den puritanska kulturen.

I A Token for Children finns det förvånande nog inte några betydande skillnader mellan hur pojkarna respektive flickorna beskrivs och det görs inte heller någon skillnad mellan pojkarnas och flickornas inlärning. Vid endast ett tillfälle kommenteras barnets kön och det sker i exempelberättelse 11:

51. She had a very strong Faith in the doctrine of the Resurrection, and did greatly solace her Soul with excellent Scriptures, which do speak the happy state of Believers as soon as their Souls are separated from their Bodies, and what she quoted out of the Scripture she did excellently and suitably apply to her own use, incomparably above the common reach of her sex and age. /.../ ${ }^{39}$

Det här är den enda kommentar jag har funnit avseende flickors (kvinnors) intellektuella kapacitet och den används för att visa hur ovanligt begåvad Susanna Bicks var. Om detta är Janeways egen kommentar kan vi inte veta. Själv påstår han i texten att berättelsen skrevs på holländska, översattes till skotska för att därefter översättas till engelska av honom själv "with a little alteration of the stile (for the benefit of English Children)" ${ }^{40}$

\section{Textens subversiva drag}

Som modern läsare förväntar man sig kanske inte att finna drag av subversiv opposition mot vuxna och vuxenvärlden i en religiös text från 1600-talet. Den subversivitet som uppmuntras i texten är visserligen av ett stillsamt och typiskt religiöst slag, men dess genomslagskraft är trots detta oerhört stark, eftersom det handlar om att bygga upp en inre, individuell styrka utifrån den personliga övertygelsen, vilket i bokens exempel leder till yttre inflytande. Denna puritanska individualism går på sätt och vis stick i stäv med den strängt religiösa kollektivismen, men kan ha bidragit till rörelsens politiska slagkraft. Det må ha varit en oavsiktlig konsekvens, men det subversiva budskapet finns där och är textens mest intressanta och dynamiska fenomen. Det bidrog sannolikt till att boken blev mycket populär bland barn.

Det vanligaste exemplet på ett subversivt beteende är att ett barn predikar till en vuxen, men det finns också tillfällen då barnen $\mathrm{i}$ texten uttrycker mer allmängiltiga omdömen, som i exempelberättelse fyra:

9. She would say, that it was the duty of Parents, Masters and Minstresses, to reprove (those under their charge) for sin, else God will meet with them. ${ }^{41}$

Flickans kategoriska uttalande inrymmer en för tiden kraftfull kritik mot vuxenvärlden och får stå oemotsagd i sammanhanget.

Att ett barn predikar till en pastor hör till undantagen, men förekommer i berättelsen om John Sudlow.

28. An hour and an half before his Death, the same Minister came again to visit him, and asked him, John, art thou not afraid to die: He answered, No, if the Lord will but comfort me in that hour. But said the Minister, How canst thou expect Comfort seeing we deserve none? He answered, No, if I had my deserts I had been in hell long ago. But, replied the Minister, which way dost thou expect Comfort and Salvation, seeing thou art a Sinner. He answered, In Christ alone. - In whom, about an hour and an half after, he fell asleep, saying he would take a long sleep, charging them that were about him not to wake him. /.../

He dyed when he was twelve years three weeks and a day old. ${ }^{42}$ 
Samtalet är anmärkningsvärt, inte minst ur den sociala aspekten. Johns övertygelse förefaller vara starkare än pastorns, vilket får en subversiv effekt.

Det finns även exempel på tuffare predikningar till vuxna, och då oftast till föräldrar, som i berättelsen om John Harvy. Han tillrättavisar sin mor med följande ord:

45. But seeing all this did rather increase then allay his Mothers grief, he was more troubled, and asked her whet she meant, thus to offend God; know you not, that it is the hand of the Almighty. Humble your self under the mighty hand of God, lay your self in the dust, and kiss the rod of God, and let me see you do it in token of your submission to the will of God, and bow before him. Upon which raising up himself a little, he gave a lowly bow, and spake no more: but went chearfully and triumphingly to Rest, in the bosome of Jesus. ${ }^{43}$

Texten framställer modern som en tvivlare, eftersom hon inte vill acceptera att det är Guds vilja att sonen ska dö, medan pojken framstår som en förkunnare av Guds ord.

Den fromma predikarens privilegierade position legitimeras också av Janeways inledande citat ur Psaltaren 8.2: "Out of the Mouth of Babes and Sucklings hast thou ordained strength." Citatet visar att texten är tänkt att ha dubbla mottagare, att budskapet i barnens mun är lika värdefullt för vuxna som för barn. Det ger den religiösa retoriken en oavsiktlig laddning, som handlar lika mycket om en omvänd maktbalans som det egentliga budskapet. Man skulle nästan kunna se barnens överdrivna fromhet som något av ett diskret uppror, inom ramen för det som förväntades men ändock - genom tro, empati och självkontroll - en styrkedemonstration i en situation där de av yttre och naturliga skäl befann sig i underläge. Den retoriska tvångströjan och den uttalade mål- sättningen finns där, men realismen och identifikationen med bokens hjältar bidrar oavsiktligt till frigörandet av textens subversiva och individualistiska budskap.

\section{Går du villigt in i döden?}

Döendet är ett centralt tema i boken. Det mod och den starka övertygelse barnen uppvisar inför sin död är menat att frammana beundran hos läsaren, något som tydligen gick hem hos William Godwin (1756-1836), som läste Janeways A Token for Children i sin barndom och har fällt följande kommentar om bokens unga hjältar och hjältinnor: ${ }^{44}$

Their premature eminence, suited to my own age and situation, strongly excited my admiration. I felt as if I were willing to die with them if I could with equal success engage the admiration of my friends and mankind. ${ }^{45}$

En fråga som återkommer gång på gång till barnen i berättelserna är:" Are you willing to die?" Det sägs exempelvis i berättelse fyra:

13. When she was taken sick, one asked her whether she were willing to die? She answered, Yes, if God would pardon her sins./ $\ldots /{ }^{46}$

Det frågan implicerar är om barnet möter döden med tillit och glädje. Den är central och direkt kopplad till uttrycket "Joyful Deaths" i bokens titel. Den ideologiska innebörden är att den som är stark i sin tro klarar av att släppa sin rädsla, har modet att överge livet för att möta döden med glädje. Det krävs, enligt texten, betydligt större mod för det än för att uthärda fysiskt lidande. Det finns flera verser som omtalar hur barnens själsliga vånda plågade dem mer än den kroppsliga smärtan. I den sjunde berättelsen står det till exempel: "Now the plague upon his body seemed nothing to that which was in his soul." ${ }^{47}$ Den som är svag klamrar sig fast vid rädslan och kroppen, är "ovillig". 
Motståndet ligger inte enbart i innebörden, utan även i själva ordets värdeladdning, där dess positivt laddade motsats "willing" banar väg för idén om döden som en välsignelse för den troende. Frågan kompletteras med bekräftande ordval i samband med barnens död. Inför det definitiva avskedet söker berättaren efter positiva tecken i barnets sista ord och uttryck som kan tyda på en gynnsam hädanfärd. Flickan i kapitel fyra beskrivs på följande sätt när hon dör:

14. She said, she did believe in Christ, and desired, and longed to be with him, and did with a great deal of chearfulness give up her soul. ${ }^{48}$

Orden "desired", "longed to" och" chearfulness" är positivt laddade och formuleringen "give up her soul" tyder på att själva döendet ses som en frivillig och medveten akt. ${ }^{49}$ Dessa uttryck fungerar som retoriska markörer, som används för att förstärka uppfattningen att barnet dog i den eftersträvansvärda sinnesstämningen. Exemplet är typiskt för hur dödsögonblicket beskrivs i bokens berättelser. I några fall brister barnen ut $\mathrm{i}$ hänryckt åkallan innan de dör. I sitt transliknande tillstånd, som Janeway kallar "Divine Rapture", talar Sarah Howley om det glädjefyllda i döden: ${ }^{50}$

/.../ O how happy am I that am going to everlasting Joyes! I would not go back again for twenty thousand worlds; And will not you strive to get an interest in Christ? ${ }^{51}$

/.../ How long sweet Jesus, finish thy work sweet Jesus, come away sweet dear Lord Jesus, come quickly / .../ Good Lord give patience to me to wait thy appointed time $/ \ldots /{ }^{52}$

Utropen kan mycket väl tolkas som en döendes längtan efter att slippa sjukdomens plågor, men budskapet befästs likväl med säker hand.

När man studerar hur barnens fromhet skildras i förhållande till deras förestående död aktualiseras frågan om författarens motiv. Detaljerna i dödsscenerna och den uppenbara fascinationen över barnens mod och övertygelse ger allt annat än ett dogmatiskt intryck. Trots de teser som texten förfäktar förefaller drivkraften vara en förundran över döendets mysterium och en uppriktig undran över vad fromhet egentligen är.

\section{Diskussionsfrågor}

Ett studium av en text som A Token for Children väcker en mängd olika frågor. En given fråga är naturligtvis varför den äldre barnlitteraturen fortfarande är ett outforskat område, i synnerhet i Sverige. Varför uppmärksammas inte de äldre, religiösa barnbokstexterna mer, särskilt med tanke på att de dominerar den äldre barnlitteraturen? Är det texternas religiösa budskap och retorik som utgör hindret? När kommer vi att kunna besvara frågor som: Har det någon betydelse för den svenska barnlitteraturen att dess historiska vagga domineras av kristen retorik och kristna värderingar?

Min förhoppning är att artikeln har visat att texter som A Token for Children är mer spännande och givande som studieobjekt än vad det kan verka vid första anblicken.

Artikeln sammanfattar delar av magisteruppsatsen Låt barnen komma till mig. En analys av puritansk retorik i Janes Janeways text "A Token for Children: Being An Exact Account of the Conversion, Holy and Exemplary Lives, and Joyful Deaths, of several Young children" av Lotta Paulin, framlagd vid Institutionen för litteraturvetenskap och idéhistoria, Stockholms Universitet, hösten 2004. 


\section{Noter}

${ }^{1}$ Children's Literature; An Illustrated History, red. Peter Hunt, Oxford University, Oxford 1995, s. 21 och William Sloane, Children's Books in England \& America in the Seventeenth Century, King's Crown, New York 1955, s. 44.

${ }^{2}$ Av berättelserna framgår att det fanns församlingsmedlemmar som ensamma eller i grupp gick runt och besökte sjuka och döende trosfränder.

${ }^{3}$ Janeway, James, A Token for Children: Being An Exact Account of the Conversion, Holy and Exemplary Lives, and Joyful Deaths, of several Young children Del 1: Dorman Newman (London, 1676). Faksimil: Classics of Children's Literature 1621-1932, red. Alison Lurie och Justin G. Schiller, Garland (New York, 1977). Exempelberättelse 2, vers 26, s. 26.

Typsnittet i citaten är normaliserat.

${ }^{4}$ Janeway, James, A Token for Children: Being An Exact Account of the Conversion, Holy and Exemplary Lives, and Joyful Deaths, of several Young children. Del 2: Dorman Newman (London, 1673). Faksimil: Classics of Children's Literature 1621-1932, red. Alison Lurie och Justin G. Schiller, Garland (New York, 1977). Exempelberättelse 11, vers 34-35, s. 42.

${ }^{5}$ B. Rud Hall, Till Gefle Läroverks historia 15571850. Urkunder samlade och kommenterade.

Årsböcker i svensk undervisningshistoria 68-69. 1943, datering i serien 1944.

${ }^{6}$ Bengt Hellekant, Engelsk uppbyggelselitteratur $i$ svensk översättning intill 1700-talets mitt. Samlingar och studier till Svenska kyrkans historia 10. Stockholm, 1944.

${ }^{7}$ Göte Klingberg, Svensk barn- och ungdomslitteratur 1591-1839, Natur och Kultur, Stockholm, 1964.

${ }^{8}$ Klingberg kritiserar Hall för två faktafel. Det ena är Halls påstående att samfundet Pro fide et christianismos låg bakom den första svenska översättningen. Klingberg invänder att det bildades först 25 år senare. Det andra är Halls uppgift att 1798 års upplaga innehöll ett urval ur Rambachs Barnabok, vilket enligt Klingberg inte är korrekt. Se Klingberg 1964, s. 30 , not 78 och 80 .
${ }^{9}$ Harvey Darton, Children's Books in England. Five Centuries of Social Life, Cambridge University, Cambridge 1932.

${ }^{10}$ Klingberg 1964, s. $30 f$.

${ }^{11}$ David Stannard, The Puritan Way of Death: A Study in Religion, Culture, and Social Change, Oxford University, Oxford, 1980, s. 25ff.

12 Alf Tergel, Från Jesus till Moder Teresa, Verbum, Stockholm, 1973, s. 218, 250f.

${ }^{13}$ Edmund S. Morgan, Visible Saints. The History of a Puritan Idea, New York University, New York, 1963, s. 15 och Tergel, 1973 s. 252.

${ }^{14}$ William Sloane, Children's Books in England \& America in the Seventeenth Century, King's Crown, New York, 1955, s. 8 och John Sommerville, The Discovery of Childhood in Puritan England, The University of Georgia, Athens, Georgia, 1992, s. 23.

${ }^{15}$ Children's Literature; An Illustrated History, 1995, s. 102.

${ }^{16}$ Puritanerna dominerade barnlitteraturen helt, men det fanns enstaka författare som tillhörde andra frikyrkor, som baptister och kväkare. Sommervilles definition av puritan respektive frikyrklig ("Dissenting") lyder: "Puritans are those who campaigned for changes in the church; Dissenters those who were cast out of the church after 1662." Se Sommerville 1992, s. 23ff. De Sommerville kallar Dissenters var i de allra flesta fall puritanska separatister, som Janeway. De begrepp som används för att kategorisera olika grenar av puritanismen (som "NonConformist", "Congregational",

"Independist", "Separatist", "Dissenting" och "Presbyterian") blandas friskt inom sekundärlitteraturen, vilket ger upphov till förvirring inte bara hos den nyfikne läsaren, utan även inom disciplinen. Därav Klingbergs misstag att kalla Janeway "presbyteriansk predikant". Klingberg 1964, s. 30. Se Alf Tergel, Från Jesus till Moder Teresa, Verbum, Stockholm, 1973, s. 291 och Edmund S. Morgan, Visible Saints. The History of a Puritan Idea, New York University, New York ,1963, s. $12 f$.

${ }^{17}$ Sommerville 1992, s. 43. 
18 Sommerville 1992, s. 53.

${ }^{19}$ Children's Literature; An Illustrated History 1995, s. 22.

${ }^{20}$ Eugene White, Puritan Rhetoric: the Issue of Emotion in Religion, Southern Illinois University, Carbondale, 1972, s. 203.

${ }^{21}$ White 1972, s. 202.

${ }^{22}$ http:/ / www.apuritansmind.com/ WilliamPerkins/WilliamPerkins.htm. Enligt White kommer uppgifter om Perkins retorikmodell ur The Arte of Prophecying. White 1972, s. 203. Årtal saknas och boken återfinns ej via sökning i bl a Library of Congress.

${ }^{23}$ http:// reference.allrefer.com/encyclopedia/ U/Udall-Ud.html. White hänvisar till Everett Emerson, "John Udall and the Puritan Sermon", The Quarterly Journal of Speech, 44 (oktober 1958), s. 282-284. Se White 1972, s. 203.

${ }^{24}$ White 1972, s. 18.

${ }^{25}$ White 1972, s. 19.

${ }^{26}$ White 1972, s. 20 f.

${ }^{27}$ Första delens bibelord lyder: "Suffer little Children to come unto me, and forbid them not: for of such is the Kingdom of God" (Mark 10.14). Andra delens bibelord är: "Out of the Mouth of Babes and Sucklings hast thou ordained strength" (Psal. 8.2). Berättelserna i $A$ Token for Children kan ses som belysande just dessa bibelord.

${ }^{28}$ Se Janeways förord samt även Harvey Darton, Children's Books in England. Five Centuries of Social Life, Cambridge University, Cambridge 1932, s. 55 och John Rowe Townsend, Written for Children, The Bodley Head, London, 1990, s. 6.

${ }^{29}$ Janeway 1676, första delen, s. A3.

${ }^{30}$ Se till exempel Janeway 1676, del 1, exempelberättelse 7 , vers 2 , s. $58 \mathrm{f}$.

${ }^{31}$ Janeway 1676, det första förordets slutord.

32 Janeway 1676, s. A3.

33 Janeway 1676, det andra förordets första sida, sidnummer saknas.
${ }^{34}$ Till exempel Janeway 1676, s. A4.

${ }^{35}$ Janeway 1676, det andra förordet, punkt 3.

${ }^{36}$ Janeway 1676, det andra förordet, punkt 4.

${ }^{37}$ Janeway 1676, det andra förordet, punkt 1.

${ }^{38}$ Se till exempel Janeway 1676, andra förordets första sida.

${ }^{39}$ Janeway 1673, del 2, exempelberättelse 11, vers 51 , s. $50 \mathrm{f}$.

${ }^{40}$ Janeway 1673, del 2, exempelberättelse 11, vers 4 , s. $23 \mathrm{f}$.

${ }^{41}$ Janeway 1676, del 1, exempelberättelse 4, vers 9 , s. 15.

${ }^{42}$ Janeway 1673, del 2, exempelberättelse 8, vers 28 , s. 13 .

${ }^{43}$ Janeway 1673, del 2, exempelberättelse 13, vers 45 , s. $86 f$.

${ }^{44}$ Fritänkaren Godwin var far till Mary Shelley och författare till Political Justice. Se Amy Cruse,

The Shaping of English Literature; And the

Readers' Share in the Development of its Forms,

George G. Harrap \& Company Ltd, London, 1927, s. 296.

${ }^{45}$ Cruse 1927, s. 296.

${ }^{46}$ Janeway 1676, del 1, exempelberättelse 4, vers 13 , s. 42.

${ }^{47}$ Janeway 1676, del 1, exempelberättelse 7, vers 6, s. 62 .

${ }^{48}$ Janeway 1676, del 1, exempelberättelse 4, vers 14, s. 42 .

${ }^{49}$ Uttrycket "gave up her/his soul" är ett talesätt som än i våra dagar vittnar om ideologin det härstammar ifrån.

${ }^{50}$ Janeway 1676, del 1, exempelberättelse 1, vers 27, s. 12 .

${ }^{51}$ Janeway 1676, del 1, exempelberättelse 1, vers 25 , s. 14 .

${ }^{52}$ Janeway 1676, del 1, exempelberättelse 1, vers 33, s. 17. 